\title{
ANALISIS PENGGUNAAN DAN PENATAUSAHAAN BARANG MILIK DAERAH DI PEMERINTAH KOTA MANADO
}

\author{
Fikha Kristy Bolendea ${ }^{1}$, Ventje Ilat ${ }^{2}$, Jessy Warongan ${ }^{3}$ \\ ${ }^{1,2,3}$ Jurusan Akuntansi, Fakultas Ekonomi dan Bisnis, Universitas Sam Ratulangi, Jl. Kampus Bahu, Manado, \\ 95115, Indonesia \\ E-mail : fikhakristy@gmail.com
}

\begin{abstract}
Regional Property is one part of the regional Government's assets that are very important to be used and utilized to support the running of the task principal and function of each government agency in the Permendagri 19 year 2016 on guidelines for management of regional property set up government agencies in especially the regional work unit (SKPD) which became the user of regional property to carry out the management of regional property effectively and efficiently. The purpose of this study is to determine the use and administration of local property in the City Government of Manado, especially on the Regional Financial and Asset Management Board. The method used in this research is descriptive analysis method. The results of the research show that the use and appropriation of regional property has been done in accordance with the prevailing regulations and has been running well, even in the inadequate use of assets. To the Head of Manado City BPKAD in order to continue to carry out technical training to the employees so that in the implementation of the use and administration of local property carried out property and in accordance with Permendagri 19 year 2016.
\end{abstract}

Keywords: usage and administration of regional property

\section{PENDAHULUAN}

Barang milik daerah (BMD) merupakan unsur yang sangat penting dalam penyelenggaraan pemerintahan khususnya dalam memberikan pelayanan kepada masyarakat. Pemerintah harus melakukan pengelolaan atas barang milik daerah agar dapat berguna bagi pemerintah dan masyarakat. Pengelolaan barang milik daerah adalah suatu proses dalam mengelola kekayaan yang telah ada sebelumnya atau yang diperoleh dari beban APBN/D atau perolehan lainnya yang sah yang dapat dimanfaatkan dan digunakan dalam kegiatan pemerintah maupun masyarakat. BMD adalah sumber daya ekonomi yang dikuasai atau dimiliki oleh pemerintah Pusat/Daerah maka pengelolaan barang milik daerah tersebut harus dilakukan secara baik dan benar.

Peraturan perundang-undangan terkait yang berlaku mengenai pengelolaan barang milik daerah adalah Peraturan Pemerintah Nomor 27 Tahun 2014 tentang Pengelolaan Barang Milik Daerah. Peraturan Pemerintah Nomor 27 Tahun 2014 merupakan peraturan yang mengganti Peraturan Pemerintah sebelumnya yaitu Peraturan Pemerintah Nomor 6 Tahun 2006 tentang Pengelolaan Barang Milik Daerah sebagaimana telah diubah dengan Peraturan Pemerintah Nomor 38 Tahun 2008 tentang perubahan Peraturan Pemerintah Nomor 6 Tahun 2006 tentang Pengelolaan Barang Milik daerah. Peraturan Pemerintah Nomor 27 Tahun 2014 tersebut menjadi petunjuk pelaksanaan bagi Pemerintah Daerah dalam melakukan Pengelolaan Barang Milik Daerah. Adapun petunjuk yang terkait Pengelolaan barang milik daerah diatur dalam Permendagri Nomor 19 tahun 2016 tentang Pedoman Pengelolaan Barang Milik Daerah yang mengatur lebih rinci mengenai Pengelolaan barang milik daerah. Pengelolaan barang milik daerah memiliki 11 (Sebelas) alur kegiatan dimulai dari Perencanaan Kebutuhan dan Penganggaran, Pengadaan, Penggunaan, Pemanfaatan, Pengamanan dan Pemeliharaan, Penilaian, Pemindahtanganan, Pemusnahan, Penghapusan, 
Penatausahaan, Pembinaan, Pengendalian dan Pengawasan. Dalam Pelaksanaan Penyusunan laporan keuangan daerah banyak hal yang perlu dicatat antara lain catatan laporan keuangan, laporan aliran kas, realisasi anggaran dan neraca. Pengelolaan aset daerah termasuk dalam penyusunan neraca pemerintah daerah. Neraca awal memiliki peran penting karena akan terus dipakai sebagai dasar dalam menentukan posisi keuangan pemerintah daerah, serta akan memberikan informasi penting kepada manajemen pemerintah dan stakeholder tentang posisi atau keadaan dari kekayaan atau aset daerah beserta ekuitas dananya pada tanggal tertentu (Yusuf 2013:9).

Dalam memberikan laporan pertanggungjawaban, pemerintah harus memperhatikan setiap aspek yang akan dilaporkan dalam laporan pertanggungjawaban. Pemerintah juga harus memeriksa kembali penatausahaan aset barang milik daerah apakah sudah sesuai dengan peraturan perundang-undangan yang berlaku dan sudah tercatat dengan baik. Terkadang masyarakat kurang memperhatikan apa saja yang menjadi barang milik daerah (aset) yang ada di daerah masing-masing dan apakah barang milik daerah tersebut sudah digunakan oleh pemerintah dengan baik dan benar sesuai dengan tugas pokok dan fungsinya.

\section{TINJAUAN PUSTAKA}

\subsection{Akuntansi Sektor Publik}

Akuntansi merupakan sebuah sistem yang mengumpulkan dan memproses (menganalisis, menghitung, dan mencatat) informasi keuangan megenai sebuah informasi kepada pengambil keputusan.Untuk menghasilkan informasi ekonomi, perusahaan perlu menciptakan suatu metode pencatatan, penggolongan, analisis dan pengendalian transaksi serta kegiatan-kegiatan keuangan kemudian melaporkan hasilnya.

Akuntansi sektor publik dapat didefinisikan sebagai akuntansi dana masyarakat. Dimana akuntansi dana masyarakat diartikan sebagai mekanisme teknik dan analisis akuntansi yang diterapkan pada pengelolaan dana masyarakat di lembaga tinggi Negara dan departemen dibawahnya, pemerintah daerah, Badan Usaha Milik Negara (BUMN), Badan Usaha Milik Daerah (BUMD), LSM, Yayasan social, maupun pada proyek-proyek kerjasama sektor public dan swasta. Organisasi sektor publik (OSP) adalah sebuah entitas ekonomi yang menyediakan barang dan/atau jasa publik untuk meningkatkan kesejahteraan masyarakat dan mencari keuntungan financial. (Nordiawan \& Hertianti, 2010:3). Akuntansi sektor publik pada awalnya merupakan aktivitas yang terspesialisasi dari suatu profesi yang relative kecil. Namun demikian, saat ini akuntansi sektor publik sedang mengalami proses untuk menjadi disiplin ilmu yang lebih dibutuhkan dan substansi keberadannya (Mardiasmo, 2009:1)

\subsection{Jenis - Jenis dan Standar Akuntansi Sektor Publik}

Organisasi-organisasi sektor publik sering kita jumpai dalam kehidupan kita. Dalam sehari-hari, kita berurusan dengan instansi pemerintah seperti Departemen Pendidikan, Departemen Tenaga Kerja, Kantor Catatan Sipil atau Kepolisian. Kita juga berinteraksi dengan berbagai organisasi kegamaan, seperti MUI (Majelis Ulama Indonesia), Nahdltul Ulama (NU), Muhammadiyah, PGI (Persatuan Gereja Indonesia), KGI (Konferensi Gereja Indonesia) dan lain-lain. Di bidang pendidikan dan kesehatan, kita juga mendapati beragam organisasi sektor publik, seperti Universitas, sekolah-sekolah, rumah sakit, puskesmas atau balai-balai kesehatan.Yang juga termasuk organisasi sektor publik adalah partai-partai dan LSM-LSM di berbagai bidang. Jika dilihat secara garis besar, jenis-jenis organisasi sektor publik di atas dapat dibagi menjadi tiga yaitu:

1. Instansi Pemerintah

Instansi pemerintah merupakan bagian organisasi sektor publik yang berbentuk instansi pemerintah. Pemerintah pusat termasuk didalamnya, Kementrian seperti Departemen Dalam Negeri, Departemen sosial, Departemen Keuangan, dan lain-lain. 
Pemerintah Daerah termasuk didalamnya, Satuan kerja perangkat Daerah seperti Dinas Pendidikan, Dinas kesehatan, Dinas Perhubungan, Dinas Pendapatan, dan Pengelolaan Keuangan dan Aset Daerah, Kantor catatan Sipil, dan lain-lain.

2. Organisasi Nirlaba Milik Pemerintah

Organisasi nirlaba milik pemerintah merupakan bagian organisasi sektor publik yang bentuknya bukan instansi pemerintah, tetapi dimiliki oleh pemerintah. Contohnya perguruan tinggi BHMN, rumah sakit pemerintah seprti RSCM, RS Daerah, dan yayasan-yayasan milik pemerintah.

3. Organisasi Nirlaba Milik Swasta

Organisasi nirlaba milik swasta merupakan bagian organisasi sektor publik yang dimiliki dan dikelola oleh pihak swasta. Contohnya yayasan seperti Sampoerna Foundation, Dompet Dhuafa Republika, sekolah dan universitas swasta, rumah sakit milik swasta.

Standar Akuntansi Pemerintahan, yang selanjutnya disingkat SAP adalah prinsipprinsip akuntansi yang diterapkan dalam menyusun dan menyajikan laporan keuangan pemerintah. Dengan demikian, SAP merupakan persyaratan yang mempunyai kekuatan hukum dalam upaya meningkatkan kualitas laporan keuangan pemerintah di Indonesia.

SAP dinyatakan dalam bentuk Pernyataan Standar Akuntansi Pemerintahan (PSAP) yang dilengkapi dengan pengantar Standar Akuntansi Pemerintahan, yaitu uraian yang memuat latar belakang penyusunan SAP. SAP disusun dan dikembangkan oleh Komite Standar Akuntansi Pemerintahan (KSAP) dengan mengacu pada kerangka Konseptual Akuntansi Pemerintahan, yakni prinsip-prinsip yang mendasari penyusunan dan pengembangan SAP bagi KSAP serta merupakan rujukan penting bagi KSAP, penyusunan laporan keuangan, dan pemeriksaan dalam mencari pemecahan atas sesuatu masalah yang belum diatur secara jelas dalam PSAP.

PSAP terdiri atas beberapa bagian, yaitu:

1. PSAP No. 1 tentang Penyajian Laporan Keuangan

2. PSAP No. 2 tentang laporan Realisasi Anggaran

3. PSAP No. 3 tentang Laporan Arus Kas

4. PSAP No. 4 tentang Catatan Atas Laporan keuangan

5. PSAP No. 5 tentang Akuntansi Persediaan

6. PSAP No. 6 tentang Akuntansi Investasi

7. PSAP No. 7 tentang Aset Tetap

8. PSAP No. 8 tentang Konstruksi Dalam Pengerjaan

9. PSAP No. 9 tentang Akuntansi Kewajiban

10. PSAP No. 10 tentang Koreksi Kesalahan, Perubahan Kebijakan Akuntansi dan Peristiwa Luar Biasa

11. PSAP No. 11 tentang Laporan Keuangan Konsolidasian

12. PSAP No. 12 tentang Laporan Operasional.

\subsection{Sistem Akuntansi Pemerintahan}

Pengertian Sistem Akuntansi Pemerintahan berdasarkan Peraturan Menteri Keuangan PP 71 Tahun 2010 pasal 1 adalah rangkaian sistematik dari prosedur, penyelenggaraan, peralatan, dan elemen lain untuk mewujudkan fungsi akuntansi sejak analisis transaksi sampai dengan pelaporan keuangan di lingkungan organisasi pemerintah. Sistem Akuntansi merupakan prosedur-prosedur yang harus dilaksanakan untuk menghasilkan informasi yang dibutuhkan oleh pihak-pihak di dalam dan di luar organisasi. (Hariadi, Restianto \& Bawono $2010: 112$ ).

Pengertian Sistem Akuntansi Pemerintah Daerah (SAPD) menurut Nordiawan dan Hertianti (2010) adalah serangkaian prosedur mulai dari proses pengumpulan data, 
pencatatan, pengiktisarian, sampai dengan pelaporan keuangan dalam rangka pertanggungjawaban pelaksanaan APBD yang dapat dilakukan secara manual atau menggunakan komputer. Sedangkan, Sistem Akuntansi Pemerintah Daerah menurut Permendagri Nomor 13 Tahun 2006 Pasal 232 ayat (3) meliputi serangkaian prosedur, mulai dari proses pengumpulan data, pencatatan, penggolongan, dan peringkasan atas transaksi dan/atau kejadian keuangan serta pelaporan keuangan dalam rangka pertanggungjawaban pelaksanaan APBD yang dapat dilakukan secara manual atau menggunakan aplikasi komputer. Untuk menyelenggarakan akuntansi pemerintah daerah, kepala daerah menetapkan sistem akuntansi pemerintahan daerah dengan mengacu pada peraturan daerah tentang pokokpokok pengelolaan keuangan daerah, serta disusun dengan berpedoman pada prinsip pengendalian interen dan standar akuntansi pemerintahan.

Satuan Kerja Perangkat Daerah (SKPD) merupakan entitas akuntansi dan harus melaksanakan sistem akuntansi pemerintahan daerah pada tingkat SKPD diistilahkan dengan sistem akuntansi SKPD. Sistem Akuntansi SKPD ini dilaksanakan oleh PPK-SKPD, akuntansi realisasi belanja SKPD merupakan bagian dari sistem akuntansi SKPD tersebut.

Deskripsi kegiatan Akuntansi SKPD meliputi:

1. Dalam struktur pemerintahan daerah, satuan kerja merupakan entitas akuntansi yang mempunyai kewajiban melakukan pencatatan atas transaksi-transaksi yang terjadi. Dalam konstruksi keuangan daerah, satuan kerja dibedakan menjadi: Satuan Kerja Perangkat Daerah (SKPD) dan Satuan Kerja Pengelolaan Keuangan Daerah (SKPKD). Meskipun SKPD dan SKPKD dalam arsitektur SAPD memiliki perbedaan dalam kewenangan, tetapi memiliki sifat yang sama dalam akuntansinya, yaitu sebagai satuan kerja.

2. Kegiatan akuntansi pada satuan kerja meliputi pencatatan atas pendapatan, belanja, aset, dan selain kas. Proses tersebut dilaksanakan oleh PPK-SKPD berdasarkan dokumendokumen sumber yang diserahkan oleh bendahara. PPK-SKPD melakukan pencatatan transaksi pendapatan pada jurnal khusus pendapatan, transaksi belanja pada jurnal khusus belanja, serta transaksi aset dan selain kas pada jurnal umum.

3. Secara berkala, PPK-SKPD melakukan posting pada buku besar dan menyusun Neraca Saldo secara periodik sebagai dasar pembuatan Laporan Keuangan yang terdiri atas Laporan Realisasi Anggaran, Neraca dan Catatan atas laporan Keuangan.

Tugas dari PPK-SKPD adalah:

1. Mencatat transaksi-transaksi pendapatan, belanja, aset dan selain kas berdasarkan buktibukti terkait.

2. Memposting jurnal-jurnal pendapatan, belanja, aset dan selain kas kedalam buku besarnya masing-masing.

3. Membuat laporan keuangan yang terdiri atas Laporan Realisasi Anggaran, Neraca dan Catatan atas laporan Keuangan

\subsection{Aset Tetap}

Aset tetap merupakan aset yang menjadi milik organisasi/perusahaan dan dipergunakan secara terus-menerus dalam kegiatan menghasilkan barang dan jasa organisasi/perusahaan. Dalam PSAP No. 07 tentang Akuntansi Aset Tetap menjelaskan bahwa Aset Tetap adalah aset berwujud yang mempunyai masa manfaat lebih dari 12 bulan untuk digunakan dalam kegiatan pemerintahan atau dimanfaatkan oleh masyarakat umum. Aset tetap merupakan suatu bagian utama aset pemerintah, dan karenanya signifikan dalam penyajian neraca.

Aset tetap diakui pada saat manfaat ekonomi masa depan dapat diperoleh dan nilainya dapat ditukar dengan handal. Dalam PSAP No. 07 dijelaskan untuk dapat diakui sebagai aset tetap harus dipenuhi kriteria sebagai berikut:

1. Berwujud 
2. Mempunyai masa manfaat lebih dari dua belas bulan

3. Biaya perolehan aset dapat diukur secara andal

4. Tidak dimaksudkan untuk dijual dalam operasi normal entitas; dan

5. Diperoleh atau dibangun dengan maksud untuk digunakan.

Aset tetap dinilai dengan biaya perolehan. Apabila penilaian aset tetap dengan menggunakan biaya perolehan tidak memungkinkan maka nilai aset tetap didasarkan pada nilai wajar pada saat perolehan. Pengukuran dapat dipertimbangkan bila terdapat transaksi pertukaran dengan bukti pembelian aset yang dikonstruksi/dibangun sendiri, suatu pengukuran yang dapat diandalkan atas biaya dapat diperoleh dari transaksi pihak eksternal dengan entitas tersebut untuk perolehan bahan baku, tenaga kerja dan biaya lain yang digunakan dalam proses konstruksi. Barang berwujud yang memenuhi kualifikasi untuk diakui sebagai suatu aset tetap dan dikelompokkan sebagai aset tetap, pada awalnya harus diukur berdasarkan biaya perolehan. Bila aset tetap diperoleh dengan tanpa nilai, biaya aset tersebut adalah sebesar nilai wajar pada saat aset tersebut diperoleh.

Suatu aset tetap mungkin diterima pemerintah sebagai hadiah atau donasi. Sebagai contoh, tanah mungkin dihadiahkan ke pemerintah daerah oleh pengembang dengan tanpa nilai yang memungkinkan pemerintah daerah untuk membangun tempat parkir, jalan, ataupun untuk tempat pejalan kaki. Suatu aset juga mungkin diperoleh tanpa nilai melalui pengimplementasian wewenang yang dimiliki pemerintah.

\subsection{Barang Milik Daerah}

Berdasarkan Peraturan Menteri Dalam Negeri Nomor 19 Tahun 2016, Barang Milik Daerah adalah semua kekayaan daerah baik yang dibeli atau diperoleh atas beban Anggaran Pendapatan dan Belanja Daerah maupun yang berasal dari perolehan lain yang sah baik yang bergerak maupun yang tidak bergerak beserta bagian-bagiannya ataupun yang merupakan satuan tertentu yang dapat dinilai, dihitung, diukur atau ditimbang termasuk hewan dan tumbuh-tumbuhan kecuali uang dan surat-surat berharaga lainnya.

Menurut M. Yusuf (2010:13 ) Barang Milik Daerah merupakan salah satu unsur penting dalam rangka penyelanggaran pemerintah dan pelayanan kepada masyarakat, oleh karena itu harus dikelola dengan baik dan benar sehingga akan terwujud pengelolaan barang daerah yang transparan, efisien, akuntabel dan adanya kepastian nilai yang dapat berfungsi sesuai dengan pokok dan fungsi dari pemerintah daerah.

Penggunaan adalah kegiatan yang dilakukan oleh pengguna/kuasa pengguna dalam mengelola dan menatausahakan barang milik daerah sesuai dengan tugas pokok. Barang milik daerah ditetapkan status penggunaanya untuk penyelenggaraan tugas pokok dan fungsi SKPD dan dapat dioperasikan oleh pihak lain dalam rangka mendukung pelayanan umum sesuai tugas pokok dan fungsi SKPD. Status penggunaan barang milik daerah ditetapkan dengan keputusan Kepala Daerah. Penetapan status penggunaan barang milik daerah diatur dalam Peraturan Menteri Dalam Negeri Nomor 19 Tahun 2016 pasal 48 sebagai berikut:

1. Pengguna melaporkan barang milik daerah yang diterima kepada pengelola

2. Pengelola meneliti usul pengguna barang milik daerah yang diterima pengguna untuk ditetapkan status penggunanya.

\subsection{Penatausahaan Barang Milik Daerah}

Permendagri Nomor 19 Tahun 2016 menjelaskan bahwa proses penatausahaan adalah kegiatan yang meliputi pembukuan, inventaris dan pelaporan barang milik daerah sesuai dengan ketentuan yang berlaku. Pembukuan adalah kegiatan pendaftaran dan pencatatan ke dalam daftar barang yang ada pada pengguna barang dan pengelola barang. Maksud dari pembukuan ini adalah agar semua barang yang berada dalam penguasa pengguna barang dan 
yang berada dalam pengelolaan barang tercatat dengan baik. Pengguna barang dalam melakukan pendaftaran dan pencatatan sesuai dengan Kartu Inventaris Barang (KIB).

Penatausahaan menghasilkan dokumen yang digunakan sebagai bukti untuk mencatat transaksi dalam proses akuntansi meliputi semua dokumen yakni semua barang yang dibeli atau diperoleh atas Beban Pendapatan dan Belanja Daerah (APBD) atau berasal dari perolehan lainnya yang sah, yang berada dalam penguasaan kuasa pengguna barang/pengguna barang dan berada dalam pengelolaan barang.

Berdasarkan Peraturan Menteri Dalam Negeri Nomor 19 tahun 2016 menyatakan bahwa, "Kepala Satuan Kerja Perangkat Daerah (SKPD) selaku pengguna barang daerah berwenang dan bertanggungjawab melakukan pencatatan dan inventarisasi Barang Milik Daerah yang berada dalam penguasaannya." Pencatatan barang daerah pada SKPD sangat penting dikarenakan catatan tersebut dijadikan objek audit oleh Badan Pemeriksa Keuangan (BPK) dalam meyakini penyajian laporan keuangan SKPD dan Pemerintah Daerah.

\subsection{Penelitian Terdahulu}

1. Penelitian yang dilakukan oleh Monika S. Kolinug (2015) hasil penelitian menunjukan bahwa DPPKAD Kota Tomohon sebagai pembantu pengelola telah menerapkan 6 siklus dalam pengelolaan aset tetap

2. Penelitian yang dilakukan oleh Selvina Sitorus (2015) hasil penelitian menunjukan bahwa DPPKBMD Selaku pengelola keuangan daerah Kota Tomohon belum memiliki kesiapan dalam penerapan SAP berbasis akrual

3. Penelitian yang dilakukan oleh Stanly Takunang (2016) hasil penelitian menunjukan bahwa Manajemen aset daerah di Kabupaten Kepulauan Siau Tagulandang dan Biaro merupakan bagian daripengelolaan keuangan daerah yang mengacu pada peraturan perundang-undangan pemerintah.

\section{METODE PENELITIAN}

\subsection{Jenis dan Sumber Data}

Jenis penelitian ini adalah penelitian deskriptif atau berbentuk uraian berupa Jenis penelitian ini menggunakan jenis penelitian deskriptif. Penelitian deskriptif merupakan suatu penelitian yang menggambarkan secara sistematis mengenai fakta, situasi dan aktifitas dari objek yang diteliti. Sumber data utama yang ada dalam penelitian ini diperoleh dari hasil penelitian lapangan. Pengumpulan data dilakukan dengan beberapa metode yaitu:

1. Teknik Wawancara

Teknik wawancara dilakukan dengan datang langsung pada Badan Pengelola Keuangan dan Aset Daerah (BPKAD) Kota Manado dan melakukan wawancara langsung dengan Kepala Bidang dan staf yang ada di BPKAD Kota Manado.

2. Studi Kepustakaan

Dimana penelitian ini dimaksudkan untuk mendapat data yang sifatnya teoritis melalui penelaah pada teori-teori yang dipelajari serta mencari sumber-sumber lain berdasarkan kepustakaan.

\subsection{Metode Analisis Data}

Metode analisis data yang digunakan dalam penelitian ini adalah dengan menggunakan metode analisis deskriptif yang berfungsi mendeskripsikan atau menggambarkan tentang objek yang diteliti. Metode ini dilakukan dengan cara mengumpulkan dan membandingkan data yang diperoleh sehingga memberi keterangan yang benar dan lengkap yakni tentang Penggunaan dan Penatausahaan Barang Milik Daerah pada Pemerintah Kota Manado. 


\section{HASIL ANALISIS DAN PEMBAHASAN}

\subsection{Hasil Analisis}

Berdasarkan hasil wawancara dan penelitian yang penulis lakukan pada Badan Pengelola Keuangan dan Aset Daerah Kota Manado, maka diperoleh hasil sebagai berikut.

\subsubsection{Penggunaan Barang Milik Daerah}

Dalam proses penggunaan barang milik daerah terdapat 4 (empat) proses kegiatan yang telah dilaksanakan di Badan Pengelola Keuangan dan Aset Daerah Kota Manado yaitu, a. Penetapan status penggunaan barang milik daerah; b. Pengalihan status penggunaan barang milik daerah; c. Penggunaan sementara barang milik daerah; d. Penetapan status penggunaan barang milik daerah yang dioperasikan oleh pihak lain.

Dalam penetapan status penggunaan barang milik daerah, BPKAD menfasilitasi dalam satu kegiatan yaitu kegiatan yang ditata dalam DPA yaitu penetapan status penggunaan BMD. Ketika kegiatan semua dilaksanakan, di dalam aturan dikatakan bahwa status penggunaan barang ditetapkan secara tahunan. Yang dilaksanakan oleh BPKAD yaitu diawali dengan mengirim surat kepada Kuasa Pengguna barang untuk menyampaikan usul barang milik daerah yang akan ditetapkan status pengguna barang, yaitu data yang dikirim dan/atau usulan kemudian diproses untuk dibuat SK Penetapan status pengguna barang yang ditandatangani oleh Walikota. Barang yang diadakan di SKPD atau di rehab di SKPD belum pasti bahwa status penggunaannya di SKPD tersebut, sebelum ada status pengguna dari Kepala Daerah. Seperti misalnya Dina PU rehab Kantor Camat, penggunaan dari kantor tersebut atau pembuatan itu ditetapkan di kecamatan walaupun dikerjakan, diadakan, dianggarkan di Dinas PU, itu status penggunaannya nanti ditetapkan dengan SK Walikota Penetapan Status pengguna barang.

Pengalihan status penggunaan barang milik daerah yaitu jika ada mutasi barang. Ada barang yang dialihkan status penggunaannya melalui berita acara serah terima barang. Misalnya diadakan barang di bagian perlengkapan tetapi akan digunakan oleh bagain lain, ada pengalihan status dan kemudian nantinya akan dibuat status penggunaan yang didampingi dengan BAST (berita acara serah terima) barang. Dalam pengalihan, misalnya kendaraan yang digunakan oleh anggota DPRD, ada dua pilihan yang bisa dilaksanakan yaitu BPKAD selaku pejabat penatausahaan barang yang merupakan orang ke 3 (tiga) dibawah Walikota dan Sekot, yaitu Kepala BPKAD bisa bertindak melakukan penarikan karena ada Peraturan Pemerintah Nomor 18 Tahun 2017 menyatakan bahwa anggota dewan yang sudah diberikan tunjangan transportasi tidak dapat menggunakan kendaraan dinas, dan opsi yang direncanakan yaitu pengalihan, dimana dari Sekretariat DPRD yang akan menata kendaraan tersebut, kemudian harus menyurat menyampaikan permohonan untuk pengalihan status, artinya bahwa kendaraan yang ada di DPRD akan dialihkan ke BPKAD, dan ketika dialihkan harus ditetapkan dengan Keputusan pengalihan status pengguna barang, dan kemudian ditindaklanjuti dengan BAST dan ada pengalihan status pengguna barang.

Untuk Penggunaan barang milik daerah yang dioperasikan oleh pihak lain prosesnya yaitu, ada pinjam pakai dari instansi atau daerah lain, misalnya dari provinsi atau daerah yang lain, ada penetapan status penggunaan barang milik daerah, itu ada surat pinjam pakai. Misalnya ada barang yang hanya dioperasikan oleh pihak lain, tetapi itu tercatat di SKPD yang awal. Jadi ketika barang itu diadakan, misalnya diadakan barang tetapi barang tersebut dioperasikan oleh pihak lain tetapi tercatat di SKPD tersebut status penggunanya, hanya saja pengeoperasiannya yang ada di SKPD lain. Seperti misalnya, pada bagian perlengkapan, ada barang yang dioperasikan di Kejaksaan ada pinjam pakai, jadi barang tersebut tetap tercatat di perlengakapan tetapi hanya dioperasikan oleh pihak lain. Hanya pengeopersiannya yang ditempat lain tetapi barang tersebut tercatat di SKPD yang diadakan. 


\subsubsection{Penatausahaan Barang Milik Daerah}

Terkait penatausahaan, Kepala Bidang Monitoring dan Evaluasi di BPKAD menjelaskan: Penatausahaan meliputi pembukuan, Inventarisasi dan pelaporan yang dilaksanakan harus sesuai dengan peraturan yang berlaku. Dalam proses pembukuan, pencatatan barang milik daerah yaitu: 1) Kartu Inventaris Barang (KIB) A: Tanah; 2) Kartu Inventaris Barang (KIB) B: Peralatan dan Mesin; 3) Kartu Inventaris Barang (KIB) C: Gedung dan Bangunan; 4) Kartu Inventaris Barang (KIB) D: Jalan, Irigasi dan Jaringan; 5) Kartu Inventaris Barang (KIB) E: Aset Tetap Lainnya; 6) Kartu Inventaris Barang (KIB) F: Konstruksi Dalam Pengerjaan. Inventarisasi dalam hal ini dapat dilakukan sensus setiap 5 (lima) tahun untuk menyusun buku inventaris dan rekap barang milik daerah. Pelaporan terdiri atas laporan barang semesteran dan tahunan, laporan tambahan aset tak berwujud, dan aset lain-lain.

Pelaksanaan kegiatan penatausahaan meliputi pembukuan, inventarisasi dan pelaporan. Pembukuan yaitu pencatatan barang yang digunakan oleh pengguna barang agar barang yang digunakan tercatat dengan baik. Pemerintah Kota Manado melalui SKPD yang bersangkutan melakukan pencatatan barang milik daerah sesuai dengan spesifikasi :

1) Kartu Inventaris Barang (KIB) A: Tanah

2) Kartu Inventaris Barang (KIB) B: Peralatan dan Mesin

3) Kartu Inventaris Barang (KIB) C: Gedung dan Bangunan

4) Kartu Inventaris Barang (KIB) D: Jalan, Irigasi dan Jaringan

5) Kartu Inventaris Barang (KIB) E: Aset Tetap Lainnya

6) Kartu Inventaris Barang (KIB) F: Konstruksi Dalam Pengerjaan

Berdasarkan wawancara diatas dapat diuraikan bahwa proses penggunaan barang milik daerah pada Badan Pengelola Keuangan dan Aset Daerah Kota Manado, yaitu diawali dengan:

1. SKPD membuat laporan barang milik daerah yang dimilikinya baik barang bergerak atau yang tidak bergerak disertai dengan usulan status penggunaan kepada Walikota melalui Sekertaris Daerah selaku pengelola BMD.

2. Setelah mendapat usulan pengguna barang, kemudian selanjutnya diteliti dan ditetapkan status penggunaannya oleh Walikota.

3. Setelah di tetapkan status penggunaannya maka SKPD melakukan inventaris dan pencatatan terhadap BMD yang di pergunakannya dalam rangka penggunaan barang milik daerah yang menunjang tugas pokok dan fungsi penyelenggraan Pemerintatah Daerah Kota Manado.

4. Selanjutnya BPKAD membuat surat keputusan tentang penetapan status penggunaan barang milik daerah yang ditandatangani oleh Walikota.

5. Setelah mendapat persetujuan dari Kepala Daerah dalam hal ini Walikota Manado maka SKPD sebagai pengguna barang tersebut mendapat status pengguna barang.

\subsection{Pembahasan}

Secara umum Badan Pengelola Keuangan dan Aset Daerah (BPKAD) Kota Manado telah melaksanakan Permendagri 19 Tahun 2016 tentang Pedoman Pengelolaan Barang Milik Daerah. Dalam aturan Permendagri 19 Tahun 2016 diatur tentang bagaimana penggunaan dan penatausahaan barang milik daerah. Dimana penggunaan barang milik daerah meliputi: Penetapan status penggunaan barang milik daerah, Pengalihan status penggunaan barang milik daerah, Penggunaan sementara barang milik daerah; d.Penetapan status penggunaan barang milik daerah yang dioperasikan oleh pihak lain. Penatausahaan memiliki tiga (3) alur kegiatan yaitu: Pembukuan, Inventarisasi dan Pelaporan. Pada dasarnya dilakukan untuk menghasilkan informasi yang andal dalam pelaporan keuangan Pemerintah Daerah, sebagai upaya meningkatkan efisiensi, efektivitas dalam pengelolaan barang itu sendiri, serta sebagai 
penunjang peran dan fungsi Pemerintah Daerah untuk menjalankan tugasnya dalam memberikan pelayanan kepada masyarakat yang ada di daerah itu sendiri.

\subsubsection{Analisis Penggunaan Barang Milik Daerah}

Penggunaan barang milik daerah berdasarkan Permendagri Nomor 19 tahun 2016 Pasal 46 bahwa "pengguna barang wajib menyerahkan barang milik daerah berupa tanah dan/atau bangunan yang tidak digunakan dalam penyelenggaraan tugas dan fungsi pengguna barang kepada kepala daerah melalui pengelola barang”. Status penggunaan barang milik daerah pada masing-masing SKPD ditetapkan dalam rangka menjalankan tata tertib dan pelayanan umum sesuai tugas pokok dan fungsi SKPD. Dalam penetapan status penggunaan barang milik daerah, BPKAD memfasilitasi dalam suatu kegiatan yaitu kegiatan yang ditata dalam DPA, yaitu penetapan status penggunaan BMD.

Sebelum penetapan status penggunaan barang milik daerah oleh kepala daerah, pengelola barang melakukan penelitian atas permohonan penetapan status penggunaan barang milik daerah dari pengguna barang. Penelitian oleh pengelola barang dilakukan terhadap kelengkapan dan kesesuaian dokumen yang dipersyaratkan. Jika dilihat dari peraturan yang ada dan dibandingkan dengan hasil penelitian maka dapat dikatakan bahwa proses penggunaan barang milik daerah di pemerintah kota Manado sudah berjalan sesuai dengan peraturan yang ditetapkan. Hal ini terlihat dari prosedur dalam penggunaan barang milik daerah yang sudah dilakukan sesuai dengan aturan mulai dari proses pembuatan laporan yang diusulkan untuk penggunaan barang milik daerah, sampai kepada barang tersebut telah ditetapkan status penggunaannya. Hal tersebut telah sesuai dengan apa yang diatur dalam Permendagri Nomor 19 tahun 2016. Meskipun penggunaan barang milik daerah pada pemerintahan kota Manado sudah berjalan sesuai prosedur yang ditetapkan namun dalam penggunaan belum sepenuhnya digunakan secara efektif sebagai pendukung tugas pokok dan fungsi pemerintah.

\subsubsection{Analisis Penatausahaan Barang Milik Daerah}

Terkait penatausahaan, Kepala Bidang Monitoring dan Evaluasi di BPKAD menjelaskan: Penatausahaan meliputi pembukuan, Inventarisasi dan pelaporan yang dilaksanakan harus sesuai dengan peraturan yang berlaku. Dalam proses pembukuan, pencatatan barang milik daerah yaitu: 1) Kartu Inventaris Barang (KIB) A: Tanah; 2) Kartu Inventaris Barang (KIB) B: Peralatan dan Mesin; 3) Kartu Inventaris Barang (KIB) C: Gedung dan Bangunan; 4) Kartu Inventaris Barang (KIB) D: Jalan, Irigasi dan Jaringan; 5) Kartu Inventaris Barang (KIB) E: Aset Tetap Lainnya; 6) Kartu Inventaris Barang (KIB) F: Konstruksi Dalam Pengerjaan. Inventarisasi dalam hal ini dapat dilakukan sensus setiap 5 (lima) tahun untuk menyusun buku inventaris dan rekap barang milik daerah. Pelaporan terdiri atas laporan barang semesteran dan tahunan, laporan tambahan aset tak berwujud, dan aset lain-lain.

Kegiatan penatausahaan di BPKAD kota Manado sudah berjalan sesuai dengan Permendagri Nomor 19 Tahun 2016, dimana kegiatan ini dimulai dari alur pembukuan. Pada Badan Pengelola Keuangan dan Aset Daerah (BPKAD) sudah dilakukan pembukuan akan barang milik daerah yang digunakan pada SKPD tersebut, dimanatelah dilakukan pencatatan pada Kartu Inventaris Barang A (Tanah), Kartu Inventaris Barang B (Peralatan dan Mesin), Kartu Inventaris Barang C (Gedung dan Bangunan), Kartu Inventaris Barang D (Jalan, Irigasi dan Jaringan), Kartu Inventaris Barang E (Aset Tetap Lainnya), Kartu Inventaris Barang F (Konstruksi Dalam Pengerjaan). Pencatatan ini telah sesuai dengan barang atau inventaris yang ada di SKPD tersebut. Selanjutnya setelah dilakukan pencatatan KIB dibuat daftar pengguna barang sebagaimana sesuai aturan pada Permendagri Nomor 19 Tahun 2016. Disamping KIB A-F, BPKAD pelaksanaannya ada KIB tambahan yaitu, aset tak berwujud 
dan aset lain-lain dimana untuk mengakomodir dua aset yang bisa dikelola dan yang ada. Hasil dari KIB ini dan semua laporan semester dan tahunan dilaporkan ke Pejabat Penatausahaan Barang yang mengakomodir semua aset dan dilakukan rekonsiliasi yang kemudian akan diinput di SIMDA barang milik daerah.

\section{KESIMPULAN DAN SARAN}

\subsection{Kesimpulan}

Berdasarkan hasil pengumpulan data dan hasil wawancara yang dilaksanakan penulis di Badan Pengelola Keuangan dan Aset Daerah Kota Manado, diperoleh kesimpulan sebagai berikut:

1. Pengelolaan barang milik daerah pada Pemerintah Kota Manado sudah dilakukan sesuai dengan peraturan yang berlaku, yaitu Permendagri 19 Tahun 2016 tentang Pedoman Pengelolaan Barang Milik Daerah.

2. Penggunaan barang milik daerah pada Pemerintah Kota Manado sudah sesuai dengan Permendagri Nomor 19 Tahun 2016. Namun dalam pelaksanaan penggunaan barang milik daerah masih ada beberapa pihak yang belum menggunakan barang tersebut sesuai dengan ketentuan yang berlaku.

3. Penatausahaan barang milik daerah di pemerintah Kota Manado telah dilaksanakan sesuai dengan Permendagri 19 Tahun 2016.

\subsection{Saran}

Berdasarkan hasil penelitian dan kesimpulan yang ada, maka ada beberapa saran yang ingin penulis sampaikan kepada Badan Pengelola Keuangan dan Aset Daerah Kota Manado yaitu:

1. Dalam pelaksanaan yang sudah ditetapkan, agar kedepan dilaksanakan lebih baik lagi agar supaya dalam penggunaan dan penatausahaan barang milik daerah seluruh pegawai yang ada lebih memahami bagaimana menjalankan pelaksanaan yang baik dan benar.

2. Kepada pimpinan Badan Pengelola Keuangan dan Aset Daerah (BKPAD) Kota Manado agar tetap membuat pelatihan teknis kepada pegawai dan staf yang ada, agar pelaksanaan penggunaan dan penatausahaan barang milik daerah bisa dikembangkan sesuai dengan peraturan yang telah ditetapkan oleh Pemerintah.

\section{DAFTAR PUSTAKA}

Hariadi, Pramono; Yanuar E; Bawono, Icuk Rangga. 2010. Pengelolaan Keuangan Daerah. Salemba Empat. Jakarta.

Kolinug, Monika. 2015. Analisis Pengelolaan Aset Tetap Pada Dinas Pendapatan Pengelolaan Keuangan Dan Aset Daerah Kota Tomohon. Universitas Sam Ratulangi, Manado. Jurnal EMBA ISSN 2303-1174 Vol.3 No.1 Maret 2015. Hal 818-830.

Komite Standar Akuntansi Pemerintahan. 2010. Peraturan Pemerintah Republik Indonesia Nomor 71 Tahun 2010 Tentang Standar Akuntansi Pemerintahan. Salemba Empat. Jakarta.

M. Yusuf. 2013. Langkah Pengelolaan Aset Daerah, Menuju Pengelolaan Keuangan Daerah Terbaik. Salemba Empat. Jakarta.

Mardiasmo. 2009. Akuntansi Sektor Publik. Andi. Yogyakarta.

Nordiawan, Deddi dan Hertianti, Ayuningtyas. 2010. Akuntansi Sektor Publik. Saelemba Empat. Jakarta.

Peraturan Daerah Kota Manado No. 2 Tahun 2016 Tentang Pembentukan dan Susunan Perangkat Daerah Kota Manado, menetapkan Peraturan Walikota Tentang 
Kedudukan, Susunan Organisasi, Tugas dan Fungsi serta Tata Kerja Badan Pengelola Keuangan dan Aset Daerah Kota Manado Tipe A. Manado.

Peraturan Menteri Dalam Negeri No. 13 Tahun 2006 Tentang Pedoman Pengelolaan Keuangan Daerah, Jakarta.

Republik Indonesia. 2016. Peraturan Menteri Dalam Negeri No. 19 tentang Pedoman Pengelolaan Barang Milik Daerah. Jakarta.

Republik Indonesia. 2010. Pernyataan Standar Akuntansi Pemerintahan No. 7 tentang Aset Tetap. Jakarta.

Sitorus Selvina. 2015. Analisis Kesiapan Penerapan Standar Akuntansi Pemerintah Berbasis Akrual Berdasarkan PP. No. 71 Tahun 2010 Pada Dinas Pendapatan Pengelolaan Keuangan Dan Barang Milik Daerah Kota Tomohon. Universitas Sam Ratulangi, Manado. Jurnal EMBA ISSN: 2303-1174 Vol.3 , No.1 Maret 2015. Hal 941-949.

Tukunang, Stanly. 2016. Manajemen Aset Daerah Pada Dinas Pendapatan Pengelolaan Keuangan Dan Aset Daerah Kabupaten Kepulauan Siau, Tagulandang, Biaro. Universias Sam Ratulangi, Manado. Jurnal EMBA ISSN: 2303-1174 Vol.4, No.2 Juni 2016. Hal 236-253. 